\title{
ČLÁNKY
}

\section{Jak normativní je právní komparatistika? ${ }^{1,2}$} How Normative is Comparative Law?

\author{
Uwe Kischel $^{*}$
}

\begin{abstract}
Abstrakt
Diskuse obledně metod právni komparatistiky neutuchá ani po několikea dekádách. Zatímco tradiční funkcionálni srovnáváni prevládá v praxi, postrádaji mnozi prèdstavitelé nauky „teoretickou“ stránku této metody. Tento spor se promitá do otázky o tom, jaký je význam právních norem ve srovnávacím právu. Hermeneutické rèsení, jež má značný význam pro praxi, reaguje nejen na tuto otázku, ale na celou diskusi obledně srovnávacich metod svým kontextuálnim prǐstupem. Zachovává si áakladni myšlenku funkcionální metody, ale predchází s ni spojeným problémuim. Hermeneutický prǐstup ve své podstatě vyžaduje, aby komparatista nacházel svoji cestu do cizího právního systému prostrédnictvím jebo pomalébo a opatrnébo osvojováni, a to jak po jeho normativni, take nenormativni stránce. Úcínným nástrojem v tomto procesu

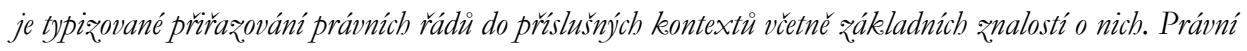
komparatistika je totiž jak normativni, tak nenormativni; použe právni norma v jejím kontextu mư̌̌e vést k. relevantnimu vísledku.
\end{abstract}

\section{Klíčová slova}

Právni komparatistika; srovnávaci metoda; funkcionálni komparatistika; hermeneutická pròstup; kontextuálni př̌stup; normativni a nenormativni kontext; ciži právni systém.

\begin{abstract}
The discussion on methods in comparative law has continued unabated for decades. While traditional, functional comparison dominates in practice, many of its academic critics deplore its lack of "theory". This conflict is exemplified by the question what is the significance of simple norms in comparative law. A practice-oriented, hermeneutical solution not only to this question but to the entire discussion on comparative methods is provided by the contextual approach to comparative law. It preserves the basic idea
\end{abstract}

* Prof. Dr. Uwe Kischel, LL.M. (Yale), attorney-at-law (New York), Katedra práva veřejného, evropského a srovnávacího (Pobaltí), Mercator-Stiftung, Greifswaldská univerzita, Německo / Department of Public Law, European Law and Comparative Law (North-Eastern Europe), Mercator-Stiftung, Faculty of Law and Economics, Greifswald University, Germany / E-mail: kischel@uni-greifswald.de

Přeložil prof. JUDr. Luboš Tichý, CSc., Centrum právní komparatistiky, Právnická fakulta, Univerzita Karlova, Praha / Centre for Comparative Law, Faculty of Law, Charles University, Prague, Czech Republic / E-mail: tichy@prf.cuni.cz / ORCID: 0000-0001-8732-0290

1 Tento př́spěvek vychází z přednášky konané dne 9. ledna 2020 na Fóru Centra právní komparatistiky Právnické fakulty Univerzity Karlovy. Přednáškový styl zůstal z větší části zachován.

2 Ke starému pojetí čistě deskriptivně chápané komparatistiky srov. DROBNIG, U. Rechtsvergleichung und Rechtssoziologie. RabelsZ, 1953, roč. 18, s. 292 (s. 295 a násl.). 
of the functional method while simultaneously avoiding its pitfalls and problems. Its hermeneutical approach in essence requires the comparatist to feel his way into the foreign legal system through a process of slow and diligent familiarization with the respective foreign law and with the normative as well as non-normative setting of the concrete rule under consideration. One helpful tool for this process is an overall type comparison of legal systems worldwide, which aggregates basic insights and experiences about these systems into a defined set of different legal contexts. Ultimately, comparative law is just as normative as it is non-normative: Only norm and context combined lead to true understanding.

\section{Keywords}

Comparative Law; Comparative Method; Functional Comparison; Contextual Approach; Hermenentical Approach; Normative and Non-normative Context; Foreign Legal System.

\section{Úvod: kritika metody a praktický postup}

Doba, kdy právní komparatistika srovnávala pouhé znění rozličných zákonů a právních norem, jako např. německý BGB a francouzský Code civil, je naštěstí již dávno pryč. $\mathrm{Z}$ dnešního pohledu lze sotva věrit, že $\mathrm{v}$ tom bylo možné vůbec spatřovat přijatelné řešení. Posuzujeme-li naproti tomu komparatistickou literaturu posledních zhruba 30 let, zjišt'ujeme, že jsou to právě metodologické otázky, které dnes hrají ústřední roli a které se v určitých vlnách znovu a znovu stávají středem pozornosti. Hlavní téma metodologicky zaměřené literatury představuje kritika funkcionálního prrístupu, který je neoddělitelně spjat se jmény Zweigerta a Kötze. ${ }^{3}$ Tato kritika se týká celé řady konkrétních aspektů. Typická výtka zní: funkcionální přístup je příliš pozitivistický. Právní komparatistika se př́liš soustřed’uje na zákony; právo je chápáno jako pouhý souhrn institucí, technik a pravidel, které jsou určeny k tomu, garantovat a podporovat individuální práva neutrálním a racionálním způsobem. ${ }^{4}$

Jako alternativa k údajnému pozitivistickému myšlení se uvádí implicitně nebo dokonce explicitně právní realismus amerického pojetí, který převládá v USA, avšak byl jen velmi omezeně akceptován mimo Spojené státy, zejména v Evropě. Poukazem na právní realismus se má na mysli, že komparatista by se neměl zabývat právními normami, nýbrž pídit se po tom, jak právní aktéři uvažuji a jak jsou činěna „,rozhodnuti““. V rámci konkrétních právních řádů jde především o postup, nikoliv o výsledek. ${ }^{5}$ Tento přístup může

3 V zásadě jde o metodologickou pasáž, která je překvapivě krátká s ohledem na její význam a vliv. In ZWEIGERT, K. a H. KÖTZ. Einfübrung in die Rechtsvergleichung. 3. vyd. Tübingen: Mohr Siebeck, 1996, s. 33 a násl.

$4 \mathrm{~K}$ tomu kritika srov. FRANKENBERG, G. Critical comparisons - Re-thinking comparative law. Harvard International Law Journal, 1985, roč. 26, s. 411 (s. 421, 433, 445); obdobně McDOUGAL, M. S. The comparative study of law for policy purposes - Value clarification as an instrument of democratic world order. In: BUTLER, W. E. (ed.). International Law in Comparative Perspective. Alphen aan den Rijn: Sijthoof \& Noordhoff, 1980, s. 191 (s. 194).

5 Přesněji srov. GERBER, D. J. System dynamics - Toward a language of comparative law? American Journal of Comparative Law, 1998, roč. 46, s. 719 (s. 722, 725 a násl., 733). 
ovšem z tradiční perspektivy lehce vést k nedorozuměním, jestliže se současně nerespektují zvláštnosti pojmu rozhodnutí v terminologii právního realismu. Termínem „rozhodnutî" se zde totiž chápe nikoliv pouhé formální rozhodnutí (tedy např. přijetí zákona nebo vydání rozsudku), nýbrž jakákoliv rozhodnutí všech právně jednajících v nejobecnějším slova smyslu. Patří sem rozdílné fenomény, jako např. rozhodnutí advokáta, kterou procesní strategii zvolí, rozhodnutí lobbisty, jak bude vysvětlovat členu parlamentu určitou právní situaci, nebo rozhodnutí o tom, jak je třeba vykládat určitý text. ${ }^{6}$ Přístup vyžaduje tedy určitou analýzu ohledně toho, jak jsou všechna tato „rozhodnuti““ činěna, jak jednotliví aktéři myslí. Proto může být nepochybně důležité vycházet z poznatků kognitivní vědy nebo sociologie. Tato alternativa k pozitivistickému myšlení by měla být významná nejen z hlediska teorie právě pro právní praxi, nebot' praktici se zajímají méně o detaily cizích právních systémů, zato daleko více o to, jak tyto systémy fungujî. ${ }^{7}$

Na osobním zážitku lze ilustrovat, jaké reakce vyvolává rozšířená kritika tohoto tradičního př́stupu v právní komparatistice: $\mathrm{v}$ reakci na moji knihu o právní komparatistice, která byla publikována nedávno, napsal mně mezinárodně známý komparatista, že má z mnoha částí literatury dojem, že právní komparatistika dnes není vůbec možná. Práce s cizím právem a jeho chápání údajně narážejí na nepřekonatelné překážky. Jeho každodenní praxe právního srovnávání však mluví zcela jinou řečí. V této každodenní pozitivní zkušenosti se mu jen potvrzuje kontextuální př́stup.

A skutečně: kontextuální právní srovnání nárokuje pro sebe bezprostřední přístup k praxi. To platí pro komparatistiku obecně, a tím též pro naše téma, tedy prístup k právním normám. Abychom načrtli v maximální zkratce náš výsledek: právní komparatistika bez právních norem je prázdná; ale právní komparatistika, která je pouze fixovaná na právní normy, je odsouzená k selhání. Abychom dosáhli tohoto výsledku a blíže vysvětlili základní kontextuální právní srovnávání, je třeba vysvětlit nejdřive metodologickou a pak praktickou perspektivu.

6 Ibid., s. 728 a násl.

7 GERBER, D. J. System dynamics - Toward a language of comparative law? American Journal of Comparative Law, 1998, roč. 47, č. 46, s. 725 a násl., s. 735; k dalším, radikálnějším přístupům postmoderny srov. např. RICHERS, D. Postmoderne Theorie in der Rechtsvergleichung? Zä̈RV, 2007, roč. 67, s. 509 (s. 521 a násl. a další prameny). 


\section{Metodologická perspektiva}

\subsection{Kritika tradičního př́stupu}

Ten, kdo dnes prochází anglicky psané články a knihy zaměřené na komparatistickou metodu za posledních 30 let, ${ }^{8}$ se dostává nezřídka do rozpaků. Připustíme-li určitý stupeň paušalizace, lze důvody takové bezradnosti bez problémů pojmenovat: především mnozí autoři používají terminologii, která osciluje mezi velmi obtížně srozumitelnou a nesrozumitelnou. To platí zejména, ale nikoliv výlučně pro autory, které lze označit jako postmoderní. ${ }^{9}$ Navíc se tyto př́ispěvky vyznačují zásadní kritikou tradiční, to znamená především funkcionální metody, a zejména jejîho zaměření na právní normy. To ovšem je, jak jsme viděli, v rozporu s praktickou zkušeností. Komparatisté pracujî totiž většinou s cizím právem a jeho právními normami každodenně, a mají přitom dojem, že tomuto právu a jeho právním normám alespoň v přijatelném rozsahu rozumějí; zaměření na právní normy se tak nejeví jako velký problém.

$8 \mathrm{Na}$ rozdíl od toho, co se občas tvrdívá, není zájem o právně-srovnávací metodu $\mathrm{v}$ žádném prípadě novým fenoménem posledních let, nýbrž sahá značně do minulosti a jako takový se ve vlnách vývoje vrací do centra pozornosti. Klasickým př́íladem rané kritiky srov. např. FRANKENBERG, G. Critical comparisons - Re-thinking comparative law. Harvard International Law Journal, 1985, roč. 26, s. 411 a násl.; srov. z posledních let kupř. HUSA, J. Farewell to functionalism or methodological tolerance? RabelsZ, 2003, roč. 67, s. 419 (s. 419 a násl.); MICHAELS, R. The functional method of comparative law. In: REIMANN, M. a R. ZIMMERMANN (eds.). The Oxford handbook of comparative law, 2. vyd. New York: Oxford University Press, 2019, s. 345; REIMANN, M. The progress and failure of comparative law in the second half of the twentieth century. American Journal of Comparative Law, 2002, roč. 50, s. 671 (s. 679 a násl.); CHODOSH, H. E. Comparing comparisons - In search of methodology. Iowa Law Review, 1999, roč. 84, s. 1025 (1025 a násl.); DEMLEITNER, N. V. Combating legal ethnocentrism - Comparative law sets boundaries. Arizona State Law Journal, 1999, roč. 31, s. 737 (s. 737 a násl.); GROSSWALD, C. V. Cultural immersion, difference and categories in U.S. comparative law. American Journal of Comparative Law, 1998, roč. 46, s. 43 (s. 67 a násl.); SACCO, R. Legal formants - A dynamic approach to comparative law. American Journal of Comparative Law, 1991, roč. 39, s. 1-34; nejnověji napr. SAMUEL, G. An introduction to comparative law and method. Oxford: Hart Publishing, 2014, passim; HUSA, J. A New Introduction to Comparative Law. Oxfort: Hart Publishing, 2015, s. 96 a násl.; KISCHEL, U. Comparative Law. New York: Oxford University Press, 2019, \ 3 marg. č. 1 a násl. [všechny citace tohoto anglického překladu odpovídají obsahově totožnému německému vydání KISCHEL, U. Recbtsvergleichung. München: C. H. Beck, 2015]; shrnující představení funkcionalistické komparatistiky např. PIEK, S. Die Kritik an der funktionalen Rechtsvergleichung. ZEuP, 2013, roč. 21, s. 60 (s. 62 a násl.).

9 Typické postmoderní príklady srov. toliko LEGRAND, P. The impossibility of ,legal transplants'. Maastricht Journal of European and Comparative Law, 1997, roč. 4, s. 111 (s. 116): „The comparatist must adopt a view of law as a polysemic signifier which connotes inter alia cultural, policitical [sic], sociological, bistorical, anthropological, linguistic, psychological and economic referents"; Ibid., s. 118: „There always remains an irreducible element of autochthony constraining the epistemological receptivity to the incorporation of a rule from another jurisdiction "; Ibid., s. 123: „Comparative legal studies is best regarded as the bermeneutic explication and mediation of different forms of legal experience within a descriptive and critical metalanguage". 
Analyzujeme-li to z ptačí perspektivy, dotýká se rozšířená kritika funkcionální metody nakonec dvou rovin. ${ }^{10}$ První se pohybuje na úrovni detailů a v jejich rámci rozpracovává a zkoumá mnohé jednotlivé aspekty funkcionální právní komparatistiky. Kritici např̀. uvádějí, že neutrální pozice vyžadovaná funkcionální metodou není uskutečnitelná, ${ }^{11}$ funkce právní normy nelze mnohdy vůbec rozpoznat, ${ }^{12}$ funkcionální komparatistika nereflektuje dostatečně právní kulturu. ${ }^{13}$ Součástí této roviny je též na počátku zmíněná kritika, že funkcionální komparatistika je údajně př́liš pozitivistická. Zadruhé kritika probíhá též na podstatně obecnější úrovni. Zde se objevuje výtka absence teorie funkcionálního právního srovnávání, absence úvah o metodě. ${ }^{14}$ Kritika požaduje překonat př́stup zdravého lidského rozumu, tak zvaný common sense approach. Právní srovnávání se musí orientovat na sociální vědy. Kritika pléduje za převzetí a používání modelů, metod a teorií sociálních věd. ${ }^{15}$ Za vědecké považuje pouze analytické metody ${ }^{16}$ vypůjčené z př́rodních věd. Jestliže právní komparatistika nepostupuje analyticky, nýbrž pouze hermeneuticky nebo fenomenologicky, pak je bez teorie, bez metody, a tudíž bezcenná. ${ }^{17}$

10 Značně detailní analýza srov. KISCHEL, U. Comparative Law. New York: Oxford University Press, 2019, $\int 3$ marg. 6 a násl., s. 147 a násl.; KISCHEL, U. La méthode en droit comparée, l'approche contextuelle. Revue Internationale de Droit Comparé, 2016, s. 907 (s. 910 a násl.).

11 Srov. např. CHODOSH, H. E. Comparing comparisons - In search of methodology. Iowa Law Review, 1999, roč. 84, s. 1050 a násl.; TSCHENTSCHER, A. Dialektische Rechtsvergleichung - Zur Methode der Komparistik im öffentlichen Recht. JZ, 2007, s. 807 (s. 811, 812); BRAND, O. Conceptual comparisons Towards a coherent methodology of comparative legal studies. Brooklyn Journal of International Law, 2007, roč. 32, s. 405 (s. 419).

12 Srov. např. McDOUGAL, M. S. The comparative study of law for policy purposes - Value clarification as an instrument of democratic world order. In: BUTLER, W. E. (ed.). International Law in Comparative Perspective. Alphen aan den Rijn: Sijthoof \& Noordhoff, 1980, s. 219, Fn. 24; BRAND, O. Conceptual comparisons - Towards a coherent methodology of comparative legal studies, Brooklyn Journal of International Law, 2007, roč. 32, s. 415 a násl.

13 Srov. např. HUSA, J. Farewell to functionalism or methodological tolerance? RabelsZ, 2003, roč. 67, s. 428; GERBER, D. J. System dynamics - Toward a language of comparative law? American Journal of Comparative Law, 1998, roč. 46, s. 722.

14 Přesně napřr. REIMANN, M. The progress and failure of comparative law in the second half of the twentieth century. American Journal of Comparative Law, 2002, roč. 50, s. 689 a násl.; srov. také JANSEN, N. Comparative law and comparative knowledge. In: REIMANN, M. a R. ZIMMERMANN (eds.). The Oxford handbook of comparative law. 2. vyd. New York: Oxford University Press, 2019, s. 291 (s. 302 a násl.).

15 Srov. např. JANSEN, N. Comparative law and comparative knowledge. In: REIMANN, M. a R. ZIMMERMANN (eds.). The Oxford handbook of comparative law. 2. vyd. New York: Oxford University Press, 2019, s. 302 a násl.; MICHAELS, R. The functional method of comparative law. In: REIMANN, M. a R. ZIMMERMANN (eds.). The Oxford handbook of comparative law. 2 vyd. New York: Oxford University Press, 2019, s. 350 a násl.; SAMUEL, G. An introduction to comparative law and method. Oxford: Hart Publishing, 2014, passim, např. s. 5, 23 a násl., s. 79.

$16 \mathrm{~K}$ rozdílům mezi analytickou a historickou problematikou a jejich metodologickými konsekvencemi srov. především SEIFFERT, H. Einführung in die Wissenschaftstheorie, Bd. 2. 11. vyd. München: C. H. Beck, 2006, s. 57 a násl., s. 234 a násl.

17 Přesně např. SAMUEL, G. An introduction to comparative law and method. Oxford: Hart Publishing, 2014, s. 119 a násl., který však pod hermeneutikou chápe něco jiného, než je zde rozebíráno. 


\subsection{Odpověd’ kontextuální právní komparatistiky}

\subsubsection{Hermeneutika namisto analytických metod}

Abychom shrnuli odpověd' kontextuální právní komparatistiky na tuto kritiku, a to ve vší stručnosti a nutně i poněkud povrchně, ${ }^{18}$ je třeba poukázat především na to, že právě tato kritika detailů funkcionální právní komparatistiky spočívá často na chybné interpretaci, a nemůže tedy dosáhnout svého cíle. Odmítnutí zdravého rozumu není již ve svém základu př́liš přesvědčivé; připouštím, že osobně jsem dokonce velkým prríznivcem zdravého lidského rozumu, který v mnoha boứlivých diskusích velmi postrádám. V právu jsme př́ležitostně nuceni akceptovat analytické metody vypůjčené ze sociálních věd. To však platí jen tehdy, jsou-li takové metody součástí dotčeného národního právního řádu. Tak tomu je např. v USA, alespoň posuzujeme-li tyto metody očima části americké právní vědy. ${ }^{19} \mathrm{~V}$ takových prrípadech musí být analytická metoda skutečně akceptována, avšak právě jako součást posuzovaného právního řádu. Se samotnou právní komparatistikou však nemá nic společného. Kritici tradiční metody importují do právní komparatistiky nakonec jeden zásadní spor vedený v sociálních vědách, když tvrdí, že jen jeden z mnoha paralelně existujících metodologických př́istupů v sociálních vědách je platný, ${ }^{20}$ totiž analytická metoda.

Pozitivně vyjádřeno, hermeneutika se hodí podstatně lépe k právnímu srovnávání nežli analytický př́stup. ${ }^{21}$ Přirozeně nepostačuje znát jen právní normy cizího práva. Naopak

18 Srov. jednotlivě KISCHEL, U. Comparative Law. New York: Oxford University Press, 2019, J 3 marg. č. 179 a násl.

19 Podstatně k pojmu „sociological jurisprudence“ POUND, R. The scope and purpose of sociological jurisprudence. Harvard Law Review, 1912, roč. 25, s. 489 (s. 489 a násl.); k pojmu ,legal realism“ FRANK, J. Law and the modern mind. New Zork: Brentano's, 1930, s. 100 a násl., passim; přehled k oběma srov. FREEMAN, M. Lloyd's introduction to jurisprudence. 9. vyd. London: Sweet \& Maxwell, 2014, s. 701 a násl., s. 823 a násl.; ke všeobecnému rozšíření právního realismu v dnešních USA srov. třeba FLEMING, J. G. The American tort process. Oxford: Clarendon Press, 1988, s. 8; SINGER, J. W. Legal realism now. California Law Review, 1988, roč. 76, s. 465 (s. 467); k otázce, zda je právní realismus zakotven především v akademickém právu, ale méně v praxi mezi americkými právníky srov. LoPUCKI, L. M. Legal culture, legal strategy, and the law in lawyer's heads. Northwestern University Law Review, 1996, roč. 90, s. 1498 (s. 1498 ).

20 Srov. např. Steuerungsgruppe der Pilotstudie Forschungsrating im Auftrag des Wissenschaftsrates, Forschungsleistungen deutscher Universitäten und außeruniversitärer Einrichtungen der Soziologie [Ř́dící skupina pilotní studie výzkumu na zadání Vědecké rady, Výzkumné služby německých univerzit a neuniverzitních sociologických institucí]. Ergebnisse der Pilotstudie Forschungsrating des Wissenschaftsrats [Výsledky hodnocení pilotního výzkumu Vědecké rady]. In: Wissenschaftsrat [online]. 16. 3. 2016, s. 33 a násl. [cit. 17. 1. 2020]. Dostupné z: https://web.archive.org/web/20160316174606/http:// www.wissenschaftsrat.de/download/Forschungsrating/Dokumente/Pilotstude_Forschungsrating Soziologie/pilot_ergeb_sozio.pdf, kteří identifikují jak kvalitativní, tak kvantitativní metody v sociologii a výslovně pak jmenují hermeneutické, konstruktivistické, systémově teoretické přístupy a zastánce racionální volby, jakož i pragmaticky orientované synkretisty.

$21 \mathrm{~K}$ hermeneutice v obecné vědě srov. SEIFFERT, H. Einführung in die Wissenschaftstheorie, Bd. 2. 11. vyd. München: C. H. Beck, 2006, s. 41 a násl., s. 69 a násl., s. 197 a násl. 
je nutné postihnout atmosféru, styl zahraničního práva a také musíme být schopni postavit právnický fenomén vždy do vztahu k celému systému, to znamená např. k jiným právním normám, k systematice cizího práva, k jeho historickému vývoji, k rozhodujícím postojům mezi obyvatelstvem, k převládající sociální situaci apod. Aby bylo možné postihnout tento komplexně chápaný celek, je zapotřebí podstatné komparatistické zkušenosti, a proto musí komparatista uplatnit určitou intuici. Tento fenomén je nakonec každému zkušenému komparatistovi známý. Současně popisuje jádro kontextuálního př́istupu.

Jednoduchý př́klad z praxe může ilustrovat nutnost brát stále $\mathrm{v}$ úvahu kontext. V jednom posudku pro rozhodčí řízení bylo třeba zodpovědět otázku, zda určitá úmluva je podle německého práva právně závaznou, anebo zda jde o pouhou gentlemanskou dohodu (gentlemen's agreement). K zodpovězení této otázky analyzoval posudek znění této úmluvy a specifikoval rozdíl mezi dvěma druhy klauzulí; na straně jedné mezi klauzulemi, které jsou formulovány jednoznačně a závazně a které samy o sobě implikují vưli k právní závaznosti, a na druhé straně měkké klauzule, které byly formulovány nanejvýš vágním způsobem. Tento rozdíl měl prokázat, že jednoznačně formulované klauzule byly zamýšleny jako kogentní, a tedy právně závazné, protože jinak by jiné klauzule nebyly formulovány záměrně měkce s cílem zabudovat do úmluvy jemné jazykové odstupňování mezi různými stupni povinností. ${ }^{22}$ Někteří z advokátů, kteří absolvovali své právnické vzdělání v USA, namítali proti této argumentační strategii, že je př́liš formalistická, ${ }^{23}$ uváděli, že tak by se nemělo a vlastně nemohlo argumentovat. Odpověd’ autora posudku poukázala naproti tomu na specifický kontext německého práva. Je to totiž německý právní styl, který je z amerického hlediska skutečně chápán jako vysoce formalistický; v rámci argumentace $\mathrm{k}$ německému právu je formální argumentace tedy nejen zcela správná, nýbrž též nutná, třebaže pro americké právníky nebude přesvědčivá.

\subsubsection{Rozdíl vìci funkecionálni komparatistice}

Obrací-li se kontextuální komparatistika proti kritice funkcionálního principu, čímž sama představuje tradiční prrístup, vyvstává vzápětí otázka, čím se pak od funkcionální komparatistiky odlišuje. Ve skutečnosti existují závažné vzájemné přesahy. Kontextuální právní komparatistika si zachovává tvrdé jádro funkcionálního myšlení, které v podstatě spočívá v tom, že prri srovnávání je třeba respektovat veškeré aspekty právního a mimoprávního kontextu každé normy. Současně se kontextuální právní srovnávání vyhýbá typickým

22 Srov. KISCHEL, U. Der Atomkonsens als rechtsverbindlicher Vertrag. Baden-Baden: Nomos, 2017, s. 16 a násl.

23 Srov. $\mathrm{k}$ formalismu především STONE, M. Formalism. In: COLEMAN, J. L. a J. S. SCOTT (eds.). The Oxford handbook of Jurisprudence and Philosophy of Law. New York: Oxford University Press, 2002, s. 166 (166 a násl.); se zvláštním shrnutím některých termínů Ibid., s. 170 a násl.; k diskuzím mezi právními realisty a formalisty BRIX, B. H. Law as an Autonomous Discipline. In: CANE, P. a M. TUSHNET (eds.). The Oxford Handbook of Legal Studies. New York: Oxford University Press, 2003, s. 975 (s. 978 a násl.); k rozdílu mezi americkým a německým pojetím formalismu srov. KISCHEL, U. Comparative Law. New York: Oxford University Press, 2019, jednak \ 6 marg. č. 88, 93, dále \5 marg. č. 257, 45 a násl. 
problémům funkcionálního prrístupu. Funkcionální komparatistika není např̀. dostatečně přizpůsobena mnohosti typů právně srovnávacích studií, které často podstatně přesahují jednoduché srovnání velmi konkrétních a specifických otázek. ${ }^{24}$ Pro takové konkrétní jednotlivé otázky - jako např̀. jak je chráněn kupující nemovitosti proti riziku koupě od nevlastníka v Německu a USA - se funkcionální komparatistika hodí znamenitě. To ale neplatí nap̌r. pro mnohé obecnější otázky, týkající se např. výkladu zákonů ve Francii a v USA, rozdílů v právnickém vzdělání mezi Českou republikou a Francií nebo významu švýcarského vlivu na dnešní turecké soukromé právo. $K$ typickým problémům funkcionálního právního srovnávání, které překonává kontextuální přístup, mohou patřit i přehnané nároky na srovnání. Př́íkladem mưže být tvrzení funkcionálních komparatistů, že srovnávány mohou být výlučně právní normy, které plní stejnou funkci. ${ }^{25}$

\subsubsection{Absence praktických diisledki kritiky}

Velmi stručný úvod do diskuse o metodě a o kontextuální komparatistice bude zakončen dvěma poznámkami. Zaprvé je z kontextuálního pohledu pozoruhodné, že kritika tradiční metody nerozvíjí většinou žádné alternativy. ${ }^{26}$ To znamená, že kritizuje, avšak nenavrhuje, jak přesně by se mělo v jednotlivostech lépe postupovat. Takové alternativní metody sice existují, ${ }^{27}$ jsou však rozvíjeny většinou zcela jinými autory. S tím souvisí též druhá poznámka: čím zásadnější je kritika tradiční právní komparatistiky, tím menšî je počet konkrétních srovnávajících studií, které zcela prakticky usilují o to, aby srovnávání na této bázi bylo prováděno lepším způsobem. Př́ležitostně lze dokonce pozorovat fenomén, že tití̌z autoři, kteří se vehementně obracejí proti tradiční komparatistice, nepostupují o mnoho jinak, když sami komparaci provádějí. ${ }^{28}$

\section{Praktická perspektiva}

\subsection{Kontexty jako typizace}

Významný německý právní teoretik Josef Esser jednou poznamenal, že praktik nechává doktrinární díla právní teorie stát s veškerou úctou na svém místě a že dokonce soudci

24 K typologii komparatistických studií srov. KISCHEL, U. Comparative Law. New York: Oxford University Press, 2019, \ 3 marg. č. 165 a násl.

25 Tak však ZWEIGERT, K. a H. KÖTZ. Einführung in die Rechtsvergleichung. 3. vyd. Tübingen: Mohr Siebeck, 1996, s. 33.

26 Pozoruhodně otevřeně třeba SAMUEL, G. An introduction to comparative law and method. Oxford: Hart Publishing, 2014, s. 173: ,it has to be admitted that the preceding chapters do not immediately reveal any coherent and schematic model of comparative law methodology. "

27 Ve shrnutí KISCHEL, U. Comparative Law, New York: Oxford University Press, 2019, 』 3 marg. č. 31 a násl.

28 Srov. třeba LEGRAND, P. Alterity - About rules, for example. In: BIRKS, P. a A. PRETTO (eds.). Themes in comparative law. New York: Oxford University Press, 2002, s. 21 (s. 21 a násl.); MENSKI, W. Hindu law - Beyond tradition and modernity. New York: Oxford University Press, 2003, passim. 
si děl právní metodologie prakticky nevšímají. Debaty o komparatistické metodě by skutečně neměly být považovány za př́liš důležité. ${ }^{29}$ Diskuse o metodě je jistě nutná. Avšak právě tak důležité je starat se o praktické aspekty právního srovnávání. V tomto případě jde především o to, dát jak mladým, tak zkušeným komparatistům do ruky nástroj, tedy nutné základní informace nezbytné $\mathrm{k}$ porozumění právním řádům, jimiž se zabývají, aby se tak mohli vyhnout omylům a chybám. Toho lze nejlépe dosáhnout tehdy, budou-li právní řády světa rozlišovány pomocí typizace (typologie) do rozdílných kontextů. Existující kontextuální základní znalosti a zkušenosti jsou pro dostatečně podobné právní řády agregovány do kontextuálního prostředí, např. do kontextu common law nebo kontinentálního evropského práva, afrického kontextu anebo různých kontextů v Asii. Kontextuální právní komparatistika se tedy vztahuje nejen na abstraktní metodologické otázky, ale rovněž na analýzu takových kontextů. Pojem kontextu postihuje přitom veškeré normativní a nenormativní, právní a neprávní elementy nejrozdílnějšího charakteru, které na právo působí. Komparatista se tak může seznamovat postupně, zcela v souladu s hermeneutickou metodou, s kontextem právních řádů, které ho zajímají.

Tyto kontexty sestávají ze značného počtu jednotlivostí, vzájemných vztahů a podrobných relevantních informací, které zde nemohou být v celém rozsahu ani naznačeny. ${ }^{30}$ Omezíme-li se však na otázku nenormativních elementů v právní komparatistice, tedy takových elementů, které nemohou být charakterizovány hezkým americkým pojmem black letter law (text právních norem), pak je alespoň možné poskytnout několik exemplárních jednohubek.

\subsection{Hranice mezi normativním a nenormativním}

Východiskem a současně centrem našeho zájmu je pojem norem (právních norem). Proto je často velmi obtížné určit v konkrétním př́padě, zda relevantní aspekt lze označit jako normativní, či nikoliv. Jestliže by byly za normativní považovány a analyzovány pouze samotné právní předpisy a jejich interpretace, byla by oblast normativního v právní komparatistice ve skutečnosti spíše omezena. Normy by v tomto spíše klasickém smyslu byly jen závaznými pravidly, jednoduše tím, co má být. Jestliže naproti tomu jako normativní budeme chápat všechna abstraktnější zobecnění materiálního obsahu práva - nap̌r. hranici mezi právem a skutečností, v praxi převládající právní teorii, vliv určitých zahraničních právních řádů - pak je normativní oblast podstatně širší. At’ je tomu jakkoliv, stále jsou zde aspekty, které lze nepochybně kvalifikovat jako nenormativní, jako tomu je např. u úrovně korupce, právnického vzdělání nebo prŕijmů advokátů, soudců nebo profesorů práva. Konečně, není podstatné, jak přesně je definována oblast normativního a nenormativního,

29 ESSER, J. Vorverständnis und Methodenwabl in der Rechtsfindung. 2. vyd. Frankfurt: Athenäum-FischerTaschenbuch, 1972, s. 7 a násl.

30 Srov. zejména a také dále KISCHEL, U. Comparative Law. New York: Oxford University Press, 2019, $\int 5-11$. 
nebot' komparatisté musejí stále zohledňovat veškeré aspekty, které pro srovnání mohou být relevantní, a to zcela nezávisle na jejich případné kategorizaci.

\subsection{Nenormativní aspekty ve světovém kontextu}

\subsubsection{Common law a kontinentálni právo: odlišné cesty?}

Na první pohled se zdá, jako kdyby v kontextech kontinentálního práva a common law nebylo již nic nového. Tyto systémy jsou ostatně již po mnoho staletí středem pozornosti komparatistů. Ve skutečnosti však existuje v těchto kontextech právě s ohledem na jejich nenormativní aspekty něco, co zasluhuje nové hodnocení.

K tomu patří např. základní zpo̊sob myšlení v common law. Tento způsob vznikal v průběhu rozsáhlého časového období, není zakotven v nějakých normách a je tedy nenormativní kategorií. Obecně se o common law soudí, že jde o induktivní myšlení případ od prŕpadu. To ovšem není zcela správné. Ve skutečnosti se pravidla common law sice získávají z jednotlivých případů induktivním způsobem, jsou však aplikována deduktivně. Na rozdíl od kontinentálního práva však nezůstávají pravidla při své aplikaci abstraktními formulacemi, ale za nimi stojící jednotlivé př́ípady si zachovávají svůj význam. ${ }^{31}$ Nově je třeba promyslet dosud rozšířenou představu, že common law se vyznačuje dlouhým a postupným rozvojem a konkretizací jednotlivých případů. To může být správné, pokud jde o každodenní aplikaci, avšak neplatí to pro velké a v centru pozornosti stojící tzv. leading cases. Ty používají naproti tomu převážně obecné principy, z nichž se pak odvozují jednotlivá řešení - konkrétní pravidla. Induktivní poukazy na předchozí judikaturu sice stále existují, nejsou však nakonec hnací silou myšlení, nýbrž slouží jen k tomu, zajistit řešení, které se od pravidla liší. ${ }^{32}$

Dalším nenormativním pozadím, jemuž přísluší v common law zásadní význam, je již zmíněný právní realismus. Jeho platnost nebo neplatnost charakterizuje ústřední, avšak ne dost často zdůrazňovaný rozdíl mezi americkým (USA) a anglickým právem. ${ }^{33}$

31 K tomu celému především KISCHEL, U. Comparative Law. New York: Oxford University Press, 2019, $\$ 5$ marg. č. 4 a násl., 40 a násl.; k pojetí common law návodně VANDEVELDE, K. J. Thinking like a lanyer An introduction to legal reasoning. 2. vyd. Cambridge: Harvard University Press, 2010, s. 67 a násl., 121 a násl.

32 Srov. tř̌ba často zmiňované rozhodnutí lorda Atkina v prípadu Donogbue proti Stevenson, 1932, AC 562 (HL), s. 578 a násl.

33 K pojetí právního realismu v USA srov. treba slavnou Singerovu formulaci: "we are all realists now" [SINGER, J.W. Legal realism now. California Law Review, 1988, roč. 76, s. 467]. Nedostatek smyslu je v Anglii obvykle vyjádřen prostým nedostatkem zmínek, ale př́ležitostně také výslovným zdůrazněním významu pravidel pro právo, odmítaným právním realismem (srov. třeba COWNIE, F., A. BRADNEY a M. BURTON. English legal system in context. 6. vyd. New York: Oxford University Press, 2013, s. 13, Fn. 58), a zdůrazňovým pozitivistickými koncepcemi (srov. ATIYAH, P. S. a R. S. SUMMERS. Form and substance in Anglo-American law. Reprint, New York: Oxford, University Press, 2002, s. 258) nebo na právní realismus přímo útočící (srov. CROSS, R. a J.W. HARRIS. Precedent in English law. 4. vyd. New York: Oxford University Press, 1991, s. 52); také občasní interní kritici zdůrazňují tradiční směřování anglického chápání práva srov. SUGARMAN, D. „A hatred of disorder“ - Legal science, liberalism and imperialism. In: FITZPATRICK, P. (ed.). Dangerous Supplements. London: Pluto Press, 1991, s. 34 (s. 34). 
Tím se vysvětluje to, proč pro anglické advokáty představuje nejhorší zkušenost setkání s americkými advokáty, kteří přiletěli do Londýna a myslí si, že ví něco o anglickém právu.

Právě tak abstraktní, přinejmenším na hranici toho, co může platit ještě jako normativní, je rozlišování mezi právem a skutečnostmi. Na první pohled se toto rozlišování jeví jako zcela jasné a univerzální. Při bližším posouzení však jde o kategorii velmi rozdílnou podle jednotlivých právních řádů. ${ }^{34}$ Vezměme za př́klad soudní rozhodnutí, které ze standardů provozní péče dovozuje pro jezdce na koni v noci povinnost jet takovou rychlostí, která mu dovolí zastavit v dohledné vzdálenosti. V Německu by takovéto rozhodnutí bylo nepochybně posuzováno jako právní otázka, tedy bylo by kvalifikováno jako normativní. V anglickém právu je to jednoznačně otázka skutková. ${ }^{35} \mathrm{Z}$ těchto rozlišení plynou početné, často překvapující a dalekosáhlé závěry, týkající se např. pravomoci jury a působnosti jejího rozhodování nebo dosahu opravných prostředků. Navíc lze na tomto základě ukázat, že common law - jinak, než je často tvrzeno - se v důsledku rostoucího počtu precedentů ne vždy dopracovává k podrobným pravidlům. ${ }^{36}$

Nenormativní pozadí, které formuje právo, existuje přirozeně právě tak v kontinentálním právu. V Německu $\mathrm{k}$ tomu pro každého německého právníka patří bez výjimky důvěrně známá technika subsumpce a znaleckého (právního) posudku. Tato technika je v Německu pokládána téměř za nejvlastnější podstatu právnického myšlení. ${ }^{37}$ Můžeme si představit údiv mnoha německých právníků, když musí konstatovat, že tato technika je v zahraničí téměř neznámá a vyžaduje podrobnější vysvětlení.

\subsubsection{Skandinávie: lagom a jiné fenomény}

Nenormativní aspekty jsou též mimořádně významné pro pochopení práva v jiných kontextech, jako např́iklad $\mathrm{v}$ kontextu skandinávském. Ten se vyznačuje mimo jiné

34 Srov. pro německé právo a common law KISCHEL, U. Der menschliche Faktor - Der Mythos der Jury im common law. In: HANDSCHEL, D. S. KIELMANSEGG, U. KISCHEL, C. KÖNIG a R. A. LORZ (eds.). Mensch und Recht - Festschrift für Eibe Riedel zum 70. Geburtstag. Berlin: Duncker \& Humblot, 2013, s. 631 (s. 633 a násl.); ke zvláštnostem a zvláště k tzv. „qualification“ ve francouzském právu KISCHEL, U. Comparative Law. New York: Oxford University Press, 2019, \6 marg. č. 141 a násl.

35 Srov. Tidy proti Battman, 1934, 1 KB 319 (CA) 319, s. 322 a násl.; Morris proti Luton Corporation, 1946, $1 \mathrm{~KB} 114$ (CA) 116.

36 Výstižně to vyjádřil lord Denning v rozsudku Qualcast (Wolverhampton) Ltd proti Haynes, 1959, AC 743 (HL), s. 748, s. 761: „... tedy jinak by prejudiciálni systém zabynul na presyceni a soudci by byli rozdrceni pod vahou sbirek svých vlastnich rozhodnuti".

37 Pro typický německý úvod určeným právním začátečníkům srov. např. VALERIUS, B. Einführung in den Gutachtenstil. 4. vyd. Heidelberg: Springer, 2017; pro úvod a rozvinutí pro neněmecké čtenáře srov. KISCHEL, U. Comparative Law. New York: Oxford University Press, 2019, \ 6 marg. č. 109 a násl.; srov. také anglickojazyčné prameny např. MARKESINIS, B. S. Tutorial and Repetitorium - Parallel and different techniques of teaching law in England and Germany. In: MARKESINIS, B.S. (ed.). The British contribution of the twenty-first century. Oxford: Hart Publishing, 2002, s. 63 (s. 83 a násl.). 
pozoruhodně malým počtem profesorů práva, což vede $\mathrm{k}$ tomu, že nezrrídka existují pro určitou právní oblast pouze jeden nebo dva akademičtí experti. Tito experti ale často také v oblasti své specializace působí v legislativě a znají tak mimořádně dobře základní legislativní podklady. ${ }^{38}$

Typický základní postoj skandinávských právníků lze vystihnout švédským slovem lagom. ${ }^{39}$ Toto slovo znamená tolik jako „akorát“, „přriměřeně“ nebo „,vhodně“, je ovšem prakticky nepřeložitelné. Označuje ve Skandinávii obecně rozšířený postoj, totiž, že nelze lámat věci násilím přes koleno, ale je třeba vhodně se přizpưsobit a jednat podle zdravého lidského rozumu. Též právo se aplikuje právě na základě tohoto př́stupu. ${ }^{40}$ To se ukazuje mimo jiné $\mathrm{v}$ mnoha každodenních maličkostech. Např́klad pro ověření listiny člověk nemusí složitě vyhledávat určitý úřad, nýbrž postačí, jestliže daný dokument svými podpisy ověří dva občané. ${ }^{41}$ Postoj lagom lze nakonec vysvětlit též jako uvolněný př́istup skandinávského práva $\mathrm{k}$ dogmatickým nebo systematickým argumentům. ${ }^{42}$ V prŕpadě nenormativního aspektu, který se často používá ve Skandinávii v rámci komparativních souvislostí, je však třeba dávat značný pozor: jde o skandinávský právní realismus podle Hägerströma. ${ }^{43}$ Ten se jednak zcela odlišuje od amerického právního

38 K tomu též RING, G. a L. OLSEN-RING. Einfübrung in das skandinavische Recht. München: C. H. Beck, 1999, s. 12; obecně k úloze a k provádění legislativních materiálů na př́kladu Švédska srov. CARLSON, L. The fundamentals of Swedish law. Lund: Studentlitteratur, 2009, s. 42 a násl.; VOGEL, H.-H. Sources of Swedish Law. In: BOGDAN, M. (ed.). Swedish Legal System. Stockholm: Norstedts Juridik, 2010, s. 20 (s. 30 a násl.).

39 K tomu a k následujícímu KISCHEL, U. Comparative Law. New York: Oxford University Press, 2019, \ 7 marg. č. 108.

40 Srov. též SANDSTRÖM, M. Den svenska modellen - en juridisk metodlära i tre platta paket. In: KEKKONEN, J. et al. (eds.). Norden, rätten, historia - Festskrift till Lars Björne. Helsinki: Finska juristföreninge, 2004, s. 291 (s. 307), která se věnuje švédské nauce o právních pramenech s ohledem na koncept pojmu „lagom“.

41 Srov. TÖNSFELDT, V. Vieles ist unkomplizierter - Im Land des Öffentlichkeitsprinzips. Anwalt, 2001, s. 20 (s. 22).

42 K tomuto volnějšímu pojetí srov. třeba NERGELIUS, J. Konstitutionellt rättighetsskydd - Svensk rätt $i$ ett komparativt perspektiv. Stockholm: Norstedts Juridik, 1996, s. 729; ZWEIGERT, K. a K. KÖTZ. Einführung in die Rechtsvergleichung. 3. vyd. Tübingen: Mohr Siebeck, 1996, s. 280; pro další vysvětlení srov. též STRÖMHOLM, S. General Features of Swedish Law. In: BOGDAN, M. (ed.). Swedish Legal System. Stockholm: Norstedts Juridik, 2010, s. 1 (s. 9).

43 Úvodem ke skandinávskému právnímu realismu např. HÄGERSTRÖM, A. Der römische Obligationenbegriff im Lichte der allgemeinen römischen Rechtsanschaunngen. Leipzig: Harrassowitz, 1927, s. 1 a násl.; anglický překlad HÄGERSTRÖM, A. Inquiries into the nature of law and morals. Wiesbaden: Harrasowitz, 1953, s. 1 a násl.; jelikož byl samotný Hägerström znám pro obtížnou srozumitelnost svých myšlenkových pochodů, lze porovnat i jejich srozumitelnější prezentaci kupř. OLIVERCRONA, K. The legal theories of Axel Hägerström and Vilhelm Lundstedt. Scandinavian Studies in Law, 1959, roč. 3, s. 125 (s. 132); SCHMIDT, F. The Uppsala school of legal thinking. Scandinavian Studies in Law, 1978, roč. 22, s. 149 (s. 153 a násl.); ALEXANDER, G. S. Comparing the two legal realisms - American and Scandinavian. American Journal of Comparative Law, 2002, roč. 50, s. 131 (s. 149 a násl.); KISCHEL, U. Comparative Law. New York: Oxford University Press, 2019, \ 7 marg č. 34 a násl. 
realismu; oba tyto směry mají společné jen své označení. Především však skandinávský právní realismus v platném právu a jeho aplikaci nehraje již žádnou roli. ${ }^{44}$

\subsubsection{Rakousko: vice nežjen malý bratr}

Němečtí, ale i jiní zahraniční právníci, často ukvapeně předpokládají, že rakouské právo je pouhou menší variantou německého práva. To nás ale lehce svádí na scestí. Jednoduchý příklad nabízí pojem správního aktu. Správní akt (Verwaltungsakt) znamená v Německu pouze administrativní úpravu konkrétního případu: $v$ Rakousku se tento pojem vztahuje na správní akt v širokém smyslu. ${ }^{45}$ Pro německého správněprávního právníka je sotva představitelné, že v Rakousku teprve od roku 2014 existuje správní soud první instance ve smyslu dvoustupňového správního soudnictví. ${ }^{46}$ Rozdíly existují však též v širších souvislostech, jako např́klad u ústavního soudnictví. Podle Konrada Lachmayera je např́íklad rakouské ústavní právo charakteristické především myšlením v kategoriích správního práva, ale i enormní složitostí ústavy a jejích rozdílných pramenů, stejně jako jeho značnou flexibilitou. ${ }^{47} \mathrm{I}$ přes pravidelná společná zasedání s rakouskými kolegy němečtí ústavní právníci tyto aspekty často bud' neznají nebo je přímo pomíjejí.

\subsubsection{Latinská Amerika: princip neprávního státu?}

V Latinské Americe hrají nenormativní aspekty zásadní úlohu: je dokonce zpochybňován význam státních právních norem. Nauka se vyjadřuje o právu Latinské Ameriky jako o „unrule of law““ ${ }^{48}$ a tedy o „neprávním státě““. ${ }^{49}$ Přitom se však nejedná o novější

$44 \mathrm{~K}$ otázce možného, ale každopádně pouze velmi nepřímého dnešního významu srov. CARLSON, L. The fundamentals of Swedish law. Lund: Studentlitteratur, 2009, s. 49; SKOGH, G. Law and economics in Sweden. International Review of Law and Economics, 1991, roč. 11, s. 319 (s. 321); velmi rezervovaně KISCHEL, U. Comparative Law. New York: Oxford University Press, 2019, \ 7 marg. č. 143 a násl.; Za zmínku zejména stojí, že standardní akademická literatura o souhrnném švédském právu nezmiňuje právní realismus ani jeho zástupce nezmiňuje, srov. BOGDAN, M. (ed.). Swedish law in the new millennium. Stockholm: Norstedts juridik, 2000, passim.

45 Srov. LOHAUS, M. Recht und Sprache in Österreich und Deutschland. Gießen: Köhler, 2000, s. 175 a násl.

$46 \mathrm{~K}$ tomu třeba stručně LACHMAYER, K. Eine Sprache, zwei Rechtskulturen - Deutsches und österreichisches Verfassungsrechtsdenken. In: KISCHEL, U. (ed.). Der Einfluss des deutschen Verfassungsrechtsdenkens in der Welt-Bedeutung, Grenzen, Zukunftsperspektiven. Tübingen: Mohr Siebeck, 2014, s. 65 (s. 79).

47 LACHMAYER, K. Eine Sprache, zwei Rechtskulturen - Deutsches und österreichisches Verfassungsrechtsdenken. In: KISCHEL, U. (ed.). Der Einfluss des deutschen Verfassungsrechtsdenkens in der Welt-Bedeutung, Grenz̧en, Zukunftsperspektiven. Tübingen: Mohr Siebeck, 2014, s. 73 a násl.

48 Srov. už v titulu GARCÍA VILLEGAS, M. Disobeying the law - The culture of non-compliance with rules in Latin America. Wisconsin International Law Journal, 2011, roč. 29, s. 263 (s. 263).

49 Srov. už v titulu MÉNDEZ, J. E., G. O'DONNELL a P. S. PINHEIRO (eds.). The (un)rule of law and the underprivileged in Latin America. Notre Dame: University of Notre Dame Press, 1999. 
fenomén, o čemž svědčí stará maxima z raně koloniálních dob: „, se obedece pero no se cumple “, 50 tedy „člověk poslouchá, avšak nerespektuje“. Lze jen předpokládat, že toto paušální rčení v mnohých státech platí více, a pro některé, jako jsou Kostarika nebo Uruguay, méně. Známá je v této souvislosti též tzv. impunidad, tj. jev, že elity často nejsou pro své protiprávní jednání volány k odpovědnosti a beztrestně unikaji. ${ }^{51}$ Při hodnocení těchto evidentně neprávních postojů je ovšem třeba určité opatrnosti. Nejedná se totiž o fenomén obecného odmítání práva, které by bylo srovnatelné s ruským právním nihilismem. Naopak v Jižní Americe paradoxně existuje vyslovené nadšení pro právo, které je spatrováno jako nástroj sociálního pokroku a změny. ${ }^{52}$

Jiný nenormativní aspekt vyplývá z existence tzv. barrios nebo favelas, tedy chudinských sídlišt' na okraji velkoměst. Zde je postupně legalizováno zpočátku ilegální obsazování pozemků. Tím se vytvořil zvláštní a současně mimoprávní systém, z něhož nakonec všichni zúčastnění profitují, a v žádném případě to nejsou jen obyvatelé těchto sídlišt'. ${ }^{53}$ Obdobně významný je též tzv. neformální sektor, tj. neoficiální trh práce, který existuje bez respektování právních předpokladů. Podle mnohých odhadů mu připadá padesátiprocentní podíl na celkovém pracovním trhu. Proč tomu tak je a čím je tento neformální sektor mimořádně trvalý, je velmi zajímavá otázka, kterou zodpovíme na jiném místě. ${ }^{54}$

$50 \mathrm{~K}$ tomu stručně AMBOS, K. Breves comentarios sobre la reforma judicial en América Latina. In: BODEMER, K. a F. CARILLO FLÓRES (eds.). Gobernabilidad y reforma política en América Latina y Europa. La Paz: GIGA et al., 2007, s. 255 (s. 257).

51 Z přeshraniční literatury k tomu právě KRUMWIEDE, H.-W. Probleme sozialer Rechtsstaatlichkeit in Lateinamerika. In: KAPPEL, R., H. W. TOBLER a P. WALDMANN (eds.). Rechtsstaatlichkeit im Zeitalter der Globalisierung. Freiburg im Breisgau: Rombach, 2005, s. 319 (s. 321).

52 Srov. třeba LINARELLI, J. Anglo-american jurisprudence and Latin America. Fordham International Law Journal, 1996, roč. 20, s. 50 (s. 59); speciálně k ústavnímu právu srov. KRUMWIEDE, H.-W. Probleme sozialer Rechtsstaatlichkeit in Lateinamerika. In: KAPPEL, R., H. W. TOBLER a P. WALDMANN (eds.). Rechtsstaatlichkeit im Zeitalter der Globalisierung, Freiburg im Breisgau: Rombach, 2005, s. 320 a násl.; GARCIA-HUIDOBRO CORREA, J. Der schwierige hispanoamerikanische Konstitutionalismus. Rechtsgeschichte, 2010, roč. 16, s. 40 (s. 46); GARCIA VILLEGAS, M. Law as hope - Constitutions, courts, and social change in Latin America. Florida Journal of International Law, 2014, roč. 16, s. 133 (s. 133 a násl.).

53 Srov. třeba KARST, K.L., M.L. SCHWARTZ a A.J. SCHWARTZ. The evolution of law in the barrios of Caracas. Los Angeles: University of California Press, 1973, s. 17 a násl.; srov. též PÉREZPERDOMO, R. Venezuela, 1958-1999 - The legal system of an impaired democracy. In: FRIEDMAN, L. M. a R. PÉREZ-PERDOMO (eds.). Legal culture in the age of globalization. Stanford: Stanford University Press, 2003, s. 414 (s. 434 a násl.); KRUMWIEDE, H.-W. Probleme sozialer Rechtsstaatlichkeit in Lateinamerika. In: KAPPEL, R., H. W. TOBLER a P. WALDMANN (eds.). Rechtsstaatlichkeit im Zeitalter der Globalisierung. Freiburg im Breisgau: Rombach, 2005, s. 329 a násl.

54 Obsáhlá socio-ekonomická analýza v PERRY, G. E. et al. (eds.). Informality - Exit and exclusion - Latin America and Caribbean Studies. Washington, D.C.: World Bank, 2007, passim; k závislosti formálních a neformálních sektorů PORTES, A. a R. SCHAUFFLER. Perspectives on the Latin American informal sector. Population and Development Review, 1993, roč. 19, s. 33 (s. 48 a násl.); k tomu všemu stručně KISCHEL, U. Comparative Law. New York: Oxford University Press, 2019, \ 7 mar. č. 188 a násl. a více pramenů. 


\subsubsection{Afrika: problémy fungováni a tradični právo}

V rozsáhlých oblastech Afriky nefunguje oficiální právní systém, zejména nefungují soudy, ${ }^{55} \mathrm{v}$ důsledku čehož nelze státním právním normám připisovat reálnou platnost. „Normativitu“ je třeba od samého počátku opatřit velkým otazníkem. Oficiální zpráva vlády Senegalu v roce 2013 dokonce uváděla, že justiční systém „neplní pro velkou část obyvatelstva svoji funkci. Je pomalý, drabý, složitý, nedostupný, nespravedlivý a často neprizppisobený sociálně kulturnimu prostredí. "56 Africké právní systémy trpí korupcí, nedostatečným právnickým vzděláním, nedostatečnou výbavou a financováním. ${ }^{57}$ Přesto: velká většina lidí $\mathrm{v}$ Africe žije právem, nechá se jím vést a důvěruje mu - avšak nejedná se o státní právo, nýbrž o nepřehlednou rozmanitost tradičních afrických práv. ${ }^{58}$ Tato tradiční práva jsou někdy oficiálně uznávána, jindy je ale stát naopak potírá. 'To však není dưležité, nebot' v každém př́padě existují tradiční africká práva s velmi komplexními obsahy a složitým vývojem, které jsou v praxi velmi účinné a fungují různým zpơsobem společně se státním právem.

\subsubsection{Cina: základni struktury státu a strany}

Právě v Asii existuje právo na velmi složitém základu, který je často velmi málo normativní. Komparatista jej však přesto musí znát, aby chápal existující právní normy. Ten, kdo pozoruje dnešní právo v Č́nské lidové republice, nachází při povrchním pohledu kupodivu málo nového nebo překvapivého, naopak se setkává s mnoha důvěrně známých obsahy,

55 Srov. kupř. MANCUSO, S. The new African law - Beyond the difference between common law and civil law. Annual Survey of International and Comparative Law, 2008, roč. 14, s. 39 (s. 39 a násl.): „,This juridical insecurity stems from the overall antiquity of the laws in force in almost all sub-Saharan countries, the inadequacy of such texts with respect to the needs of the modern economy, and the extreme delay, or even absence of publication of legal rules. The judicial insecurity mainly comes from the decay in justice due to the slowness of the cases, the unpredictability of the courts, the corruption of the judicial system, and the difficulty in enforcing the judgements. "; Ve shrnutí KISCHEL, U. Comparative Law. New York: Oxford University Press, 2019, \ 8 marg. č. 16 a násl.

56 République du Sénégal (ed.). Programme national de bonne gouvernance. In Programme d'appui à la décentralisation et au développement local. PRODDEL [online]. 04/2002, s. 46 [cit. 17. 1. 2020]. Dostupné z: https://web.archive.org/web/20160709084027/www.proddel.sn/IMG/doc_Plan_ National_Bonne_Gouvernance.doc: „Pour une grande majorité de la population, la justice ne remplit pas son rôle. Elle est lente, chère, complexe, inaccessible, inéquitable et, parfois inadapté à l'environnement socioculturel. "

57 Srov. př́kladmo prohlášení kamerunského ministra spravedlnosti, Doualy Moutomeho, z roku 1994, in Synthèse des Travaux de la Table Ronde „Justice et Institutions Financières“, édition spéciale. 1994, s. 201, citováno podle WABNITZ, H.-W. Reforming legal reform in francophone Africa - World Bank's project experience. Recht in Afrika, 2008, roč. 11, s. 147 (s. 149): „Comment peut-on espérer qu'un Magistrat mal payé, socialement déconsidéré, travaillant sans documentations dans des juridictions dépourvues de l'équipement minimum, secondé par le personnel judiciaire cuvrant depuis trop longtemps dans des juridictions d'un autre âge, sans machine à écrire, voire sans papier, puisse rendre une justice sereine et à la hauteur des enjeux essentiels qu'il a la charge de préserver?"

58 K tradičnímu právu srov. CUNIBERTI, G. Grands systèmes de droit contemporains, 4. vyd. Paris: LGDJ, 2019, s. 387 a násl.; KISCHEL, U. Comparative Law. New York: Oxford University Press, 2019, \ 8 marg. č. 24 a násl., zejména k poměru k vnitrostátnímu právu ibidem, $\int 8$ marg. č. 77 a násl., pokaždé více pramenů. 
které nakonec připomínají kontinentální právní systémy. ${ }^{59}$ Toto právo je přitom v praxi velmi důležité a nepředstavuje pouhou fasádu. Navzdory tomu není možné pominout složité struktury, které formují právní realitu rudé Číny. To platí v prvé raadě o roli komunistické strany a jejích strukturách. ${ }^{60}$ Zjednodušeně vyjádřeno, čínská komunistická strana buduje detailní struktury, které jsou paralelní s těmi státními; pro každou státní jednotku existuje odpovídající jednotka ve straně. ${ }^{61}$ Přednostní a mimořádný význam vioči státu se prriznává partajním strukturám. Na to se však často zapomíná. Důvod ${ }^{62}$ by mohl spočívat $\mathrm{v}$ často nevědomém juristickém předpokladu, že totiž majiteli moci v každém fungujícím státě jsou právě státní instituce. V Čínské lidové republice jsou státní instituce, a tedy celý stát pouze jedním, i když významným mocenským instrumentem v rukou strany. S tím není v žádném případě v rozporu, že čínská ústava komunistickou stranu vưbec nezmiňuje. Naopak, je to př́mý následek tohoto stavu. Ústava je totiž nejvyšší organizační normou státu a strana tak není státní moci podřízena. ${ }^{63}$ Tak vznikají komplikované a na první pohled rozporuplné mocenské struktury, $\mathrm{v}$ rámci nichž státní instituce stojí proti institucím stranickým, právě tak jako lokální instituce proti institucím celého státu. ${ }^{64} \mathrm{~V}$ justičním systému jsou aspekty závislosti postaveny proti aspektům nezávislosti. ${ }^{65}$ To patří k vlastnostem sinomarxismu, který s těmito rozpory nemá vůbec žádný problém. ${ }^{66}$

Dalším nenormativním aspektem, který je často a v poslední době ve zvýšené míře zmiňován v souvislosti s Čínskou lidovou republikou, je určitý vliv starého čínského

$59 \mathrm{~K}$ návaznosti vůči německému myšlení o právu, zejména v občanském právu BU, Y. Die Rezeption des ausländischen Rechts in China. In: BU, Y. (ed.). Deutsche und europäische Elemente des chinesischen Rechts. Münster: LIT, 2012, s. 1 (s. 1 a násl.); CHEN, T.-F. Transplant of civil code in Japan, Taiwan, and China With focus of legal evolution. National Taiwan University Law Review, 2011, roč. 6, s. 389 (s. 418 a násl.).

$60 \mathrm{~K}$ tomu třeba ZHANG, M. The socialist legal system with Chinese characteristics - China's discourse for the rule of law and a bitter experience. Temple International and Comparative Law Journal, 2010, roč. 24, s. 1 (s. 49 a násl.); CHEN, A. H. An introduction to the legal system of the People's Republic of China. 3. vyd. Hong Kong: LexisNexis, 2004, s. 74 a násl.; ještě základněji SENGER, H. Einfübrung in das cbinesische Recht. München: C. H. Beck, 1994, s. 38 a násl., s. 203 a násl.

61 Srov. treba ZHANG, Q. The constitution of China - A contextual analysis. Oxford: Hart Pubslishing, 2012, s. 54; Ibid., s. 84 poukazuje na uvedený velký stranický aparát, čítající miliony lidí, který je vůči státnímu úřednictvu paralelně seskupen a placen; srov. též PEERENBOOM, R. China's long march toward rule of law. New York: Cambridge University Press, 2002, s. 214.

62 Kriticky $\mathrm{k}$ banalizujícím a ignorujícím tendencím některých západních odborníků SENGER, H. Einfübrung in das chinesische Recht. München: C. H. Beck, 1994, s. 205, s. 210; kriticky k všeobecným tendencím autocenzury PIQUET, H. Le „rêve chinois“ en question - Le débat sur le constitutionnalisme en Chine. Revue française de droit constitutionnel, 2014, roč. 98, s. 389 (s. 410).

63 K tomu celému KISCHEL, U. Comparative Law. New York: Oxford University Press, 2019, \9 marg. č. 67 a násl.

64 Srov. třeba CUNIBERTI, G. Grands systèmes de droit contemporains, 4. vyd. Paris: LGDJ, 2019, s. 203, s. 210, který např. dokonce hovoří o faktickém federalismu, který se tímto způsobem vyvinul.

65 Blíže srov. KISCHEL, U. Comparative Law. New York: Oxford University Press, 2019, s. 92 a násl.

$66 \mathrm{~K}$ sinomarxismu průběžně SENGER, H. Einführung in das chinesische Recht. München: C. H. Beck, 1994, s. 207 a násl., s. 318 a násl.; speciálně ke vztahu k protiřečení Ibid., s. 230 a násl. 
myšlení, zejména konfucianismu. ${ }^{67}$ Realista však bude pocit'ovat značné pochybnosti. Během tzv. kulturní revoluce byly totiž konfucianismus a ty části společnosti, které byly jeho nositeli, radikálně vymýceny.

\subsubsection{Jihovýchodni Asie: mýtus averze ke sporim}

V jihovýchodní Asii se ukazuje, že právní rády Japonska, Tchajwanu a Jižní Koreje vykazují značné podobnosti, což umožňuje, aby se staly jádrem svébytného kontextu jihovýchodní Asie. Nenormativní aspekt, který je v tomto kontextu zmiňován, k této podobnosti spočívající v údajné averzi ke sporům mezi obyvatelstvem nepřispívá. ${ }^{8}$ Tato averze se totiž při bližším pohledu ukazuje jako neudržitelná již ze statistického hlediska. ${ }^{69}$

\section{Závěr: význam nenormativního v právní komparatistice}

Z tohoto krátkého, a dokonce bych řekl anekdotického přehledu vyplývají některé výrazné závěry pro zodpovězení otázky normativity právní komparatistiky. Na jedné straně zůstává právní srovnání, které je vztaženo jen na právní normy, neplodnou disciplínou, odsouzenou k selhání. Ukazuje se, že je nemožné chápat, jak právní systém funguje, jak jsou jeho normy aplikovány a jak dochází k závěrům, aniž bychom znali nenormativní kontext a jeho reflexi. Tento poznatek je méně překvapivý sám o sobě; velmi překvapivá je skutečnost, že význam nenormativního v rámci většiny národních právních řádů zůstává obvykle nevyřčen. Ale i to je nakonec pochopitelné. Velká většina právníků čistě orientovaných na domácí právo považuje nenormativní elementy svého vlastního právního systému jednoduše za samozřejmé; jejich existence se prostě předpokládá.

67 Srov. právě již nějaký čas kolující bonmot, podle nějž označuje zkratka „KSČ““ [Komunistická strana Číny] spíše než komunistickou, právě konfucianistickou (nebo vůbec kapitalistickou) strana Č́ny; SENGER, H. Die VR China und die Menschenrechte. In: REHBEIN, B. (ed.). Identitätspolitik und Interkulturalität in Asien - Ein multidisұiplinäres Mosaik. Berlin: LIT, 2006, s. 119 (s. 122); k uvedené poznámce německého spolkového kancléře Helmuta Schmidta z roku 1984 a odpovědi Denga Xiaopinga srov. JOCKS, H.-N. „China ist ein gigantisches Experiment“. Der Tagesspiegel [online]. 6. 4.2008 [cit. 17. 1. 2020]. Dostupné z: http://www.tagesspiegel.de/kultur/interview-china-ist-ein-gigantisches-experiment/1204526.html

68 Srov. např. pro oblast Japonska klasická pojednání NODA, Y. Introduction au droit japonais. Paris: Dalioz, 1966, s. 175; KAWASHIMA, T. Dispute resolution in contemporary Japan. In: VON MEHREN, A. T. (ed.). Law in Japan - The legal order in a changing society. Cambridge: Harvard University Press, 1963, s. 41 (s. 41 a násl.); pro Asii jako celek zejména GREEN, C. J. APEC and trans-pacific dispute management. Law and Policy in International Business, 1995, roč. 26, s. 719 (s. 729 a násl.).

69 Srov. kriticky k údajné averzi vůči trestům v Asii KISCHEL, U. Comparative Law. New York: Oxford University Press, 2019, § 9 marg. č. 165 a násl.; zvláště k Japonsku CUNIBERTI, G. Grands systèmes de droit contemporains. 4. vyd. Paris: LGDJ, 2019, s. 280 a násl.; obecně ke kritice v případě Japonska právě HALEY, J. O. The myth of the reluctant litigant. Journal of Japanese Studies, 1978, roč. 4, s. 359 (s. 359 a násl.); pro objektivizaci diskuze např. BAUM, H. Rechtsdenken, Rechtssystem und Rechtswirklichkeit in Japan - Rechtsvergleichung mit Japan. RabelsZ, 1995, roč. 59, s. 258 (s. 290 a násl.), který Ibid., s. 291, varuje před ,nebulöse[n] Spekulationen im Stile einer (...) rechtsvergleichenden Märchenstunde "[mlhovitými spekulacemi ve stylu komparatistické hodinky pohádek]. 
Na druhé straně právní komparatistika bez právních norem je prázdnou, a tudíž bezpředmětnou disciplínou. V první řadě jsou to totiž právě právní normy, které právníky zajímají a jež jsou primárním objektem i právního srovnávání. Kontext je nutný, avšak jen proto, abychom normy, které jsou centrálním elementem práva, lépe chápali a abychom jejich význam, vliv a funkci dovedli ocenit. Samozrejmě je též možné zabývat se i v komparatistických studiích výlučně nenormativním kontextem, např́iklad korupcí, sociálním postavením advokátů, soudců nebo profesorů, anebo právnickým vzděláním $\mathrm{v}$ nejrůznějších právních řádech. Avšak i to je nakonec pouhým prostřredkem k určitému účelu a slouží k lepšímu pochopení fungování právních norem. Žádný z těchto poznatků nemá nic společného s druhem a rozsahem významu právních norem v národním právu, tj. s převládající právní teorií v některém státě, at’ je jí pozitivismus, přirozené právo, právní realismus anebo jiné směry. Tyto právní teorie a jejich odpovídající význam v různých státech nejsou součástí, nýbrž předmětem právní komparatistiky. 